\title{
Umbilical Cord Blood (stem cell) Banking
}

\author{
J RAHMAN
}

\begin{abstract}
Summary:
Umbilical cord blood (UCB) is a source of premature haemopoietic stem cells (HSC) and progenitor cells which has a tremendous capacity to differentiate into another type of cell. Many malignant and non-malignant disorders are being treated with the transplantation of the UCB cells. This precious thing is usually discarded. But it can be easily and safely collected, cryopreserved and stored in a cord blood bank. UCB banks are being established in many countries of the world. Two models of cord blood banking systems are available-one is Family or private banking where UCB is stored for the benefit of
\end{abstract}

\section{Introduction:}

Stem cells are at the forefront of one of the most fascinating and revolutionary areas of biology today. Scientists are rapidly discovering many revolutionary uses for stem cells, because they have the unique capability to either multiply or develop into other cell types ${ }^{1}$. Stem cell transplantation is an accepted curative therapy for many malignant and nonmalignant conditions affecting children and adults ${ }^{2}$. Umbilical cord blood (UCB) has become a widely accepted alternative source of hematopoietic stem cells (HSC) for transplantation. UCB banks are fundamental to support this increasing clinical activity. ${ }^{3}$ But, its use in adults is restricted because of low absolute HSC numbers. To overcome this obstacle, expansion of HSC in co culture with feeder cells is a promising possibility ${ }^{4}$.To date, more than 5,500 cord blood stem cell transplants from unrelated donors and several hundred from sibling donors have been performed worldwide ${ }^{5}$.

Background of cord blood transplantation: During 1970s, researchers discovered that umbilical cord blood could supply the same kinds of blood-forming (hematopoietic) stem cells as a bone marrow donor. And so, umbilical cord blood began to be collected and stored. The first successful cord blood transplant took place in France in 1988, for a child with

Address for Correspondence: Dr. Jahanara Rahman, 59, East Rajabazar, Tejgaon, Dhaka-1215, Bangladesh. Phone no. 8152550 (res), Cell: 01819-239259,E-mail: minturuma@yahoo.com

Received: 14 June, 2008

Accepted: 23 December, 2008 the donor or their family and another is non-profitable public banking where UCB is stored for research purpose and for allogeneic unrelated transplantation. About seventy diseases can be treated with $U C B$ transplantation. But, there are many debates regarding cord blood transplantation and legal and ethical issues cause to concern. However, UCB has become an established alternative to bone marrow transplantation in children and young adults.

Key word: Stem cell, cord blood banking, stem cell transplantation.

(J Bangladesh Coll Phys Surg 2009; 27: 39-44)

Fanconi's Anemia, a rare congenital anemia. Again in 1991, a transplant was performed on a child with chronic Myelogenous Leukemia. Both transplants were successful, opening the door to cord blood transplantations for situations in which traditional bone marrow had been routinely used. Since then, approximately two-thirds of the cord blood transplants performed have been for malignant conditions, while the remainders have been done for a variety of genetic blood disorders. Overall, cord blood transplants offer a high rate of success, which continues to grow as the number of transplants rises $^{1,5,6}$.

\section{What is Cord Blood?}

Cord blood is the blood that remains in the umbilical cord and placenta following birth, which is usually discarded.

\section{What does umbilical cord blood contain?}

Cord blood contains Hematopoietic stem cell. These proliferative cells have greater proliferative and colony forming capacity than the stem cells obtained from bone marrow or peripheral blood and are more responsive to some growth factors. They are more native than proliferative cells from bone marrow; they seem to produce fewer complications associated with some aspects of HSC transplantation?

Reports suggest that not only are mesenchymal and neural precursor cells present but that some cord blood cells, may have the capacity to develop into many different lineages including cartilage, fat 
cells, hepatic and cardiac cells. Research is still at an early stage and despite the amount of interest in the field ${ }^{8,9}$.

\section{What Are Stem Cells?}

Stem cells are called the master cells or mother cells of the body which can be differentiated into other kind of the cells. They can be collected from the bone marrow, peripheral blood, and embryo and from umbilical cord blood. Cord blood stem cells have tremendous capacity to differentiate and proliferate into any type of cells and it is being used in the treatment of many life threatening diseases.

\section{Source of Stem Cells for Transplantation:}

Adult Stem Cells: Adult stem cells are found in bone marrow and require invasive surgery to acquire. Also, finding a matching donor for a bone marrow transplant is difficult and sometimes impossible. Currently, peripheral blood is the most common source of stem cells for transplant. Peripheral bloodstream cells (PBSCs) are blood-forming stem cells released from the marrow into the bloodstream. But, the marrow releases only a small number of these stem cells into the blood. The number is too small to allow collection of peripheral blood stem cells for transplantation. So, to obtain enough stem cells from the peripheral blood for a transplant, prior chemotherapy or use of growth factors is needed to administer to a donor. The cells are collected from the blood using a process called Apheresis ${ }^{5,10}$.

Embryonic Stem Cells: Embryonic stem cells can be derived from an embryo, but it is highly controversial and often draws many moral and ethical debates.

Umbilical Cord Blood Stem Cells: Cord blood stem cells are collected from the umbilical cord and placenta after a baby is born. Cord and placental blood contain large numbers of blood-forming stem cells. Umbilical cord blood offers a perfectly natural method of acquiring stem cells. Cord blood stem cells offer many advantages over other stem cells. They are collected in a risk-free, five-minute procedure at the time of birth that is painless for both mother and baby. Also, stem cells from cord blood are better than stem cells from bone marrow because they are less prone to graft vs. host disease (GVHD - an immune system attack by donor cells against the recipient) and other complications relating to rejection of foreign cells. Most importantly, banked cord blood is available when needed; allowing treatment to begin almost immediately, without time spent searching for a match. Moreover, cord blood stem cells are a perfect match for the baby and can potentially be used to treat other family members ${ }^{5}$.

\section{What is cord Blood Banking?}

Preserving a newborn's stem cells for potential medical uses to treat life-threatening diseases is called cord blood banking. Cord blood banking involves several steps including collection, processing and storage ${ }^{11}$.

Umbilical cord blood collection: Cord blood collection is simple and painless and almost risk free for the mother and baby. Immediately after the delivery of the baby, the umbilical cord is clamped and the baby is separated from the cord. Cord blood can be collected in two ways-Syringe method and bag method. In syringe method, a syringe is used to draw blood from the umbilical cord. The process is basically same as drawing blood for a blood test. By bag method the needle attached to the collection bag is inserted into the vein in the umbilical cord. The placental blood/umbilical cord blood, drawn by gravity, then flows into the collection bag which is equipped with an anti-coagulant to keep the blood from clotting before it reaches the laboratory. The syringe or bag should be pre-labeled with a unique number that represents that particular baby. Cord blood may only be collected during the first 15 minutes following the birth and should be processed by the laboratory within 48 hours ${ }^{6,12}$.

\section{Amount of blood}

An adequate cord blood collection requires at least 75 $\mathrm{ml}$ in order to ensure that there will be enough cells to be used for a transplantation ${ }^{1}$.

\section{How cord Blood is processed and stored?}

After cord-blood collection has taken place, it is taken by courier service to the cord-blood bank. There the sample is given an identifying number. Then the stem cells are separated from the rest of the blood on the basis of their total nucleated cells (TNC) and CD34(+) cells and are stored cryogenically( cooled with liquid nitrogen $)^{13}$. Cord blood stem cells are 
stored in six cryovials. Thereby, it is not necessary to draw the entire specimen at once; thus it offers the potential for multiple usages. The cryovials are designed specifically for long-term cryogenic storage $^{6,12,14}$.

\section{How long can cord blood cells be stored?}

According to published research blood-forming stem cells stored up to 15 years can be used in transplants ${ }^{15}$. In fact, stem cells appropriately frozen and stored in liquid nitrogen are viable for an indefinite period. Cord blood samples have been preserved for as long as 10 years and have still been successfully transplanted ${ }^{5}$.

\section{Types of cord blood banking?}

Cord blood banking is of two types-Private or Family or directed banking and another is Public or non -directed banking:

A private bank (for-profit) offers the opportunity to bank exclusively for the donors and their family making the stem cells available when needed those most and allowing treatment to begin almost immediately without time spent searching for a match. Again, cord blood stem cells are a perfect match for the baby and can potentially be used to treat other family members ${ }^{12,16}$.

Where as, a public bank (non-profit) takes in donations for use of the greater public and research.

\section{Public versus private banking}

There has been debate about whether it is appropriate or necessary for individuals to store their child's cells in private commercial stem cell banks ${ }^{17-20}$.The causes for arguments against the necessity of private banking are:

The individual's chances of using personal cord blood for haematopoietic disorders before the age of 20 years is low; estimates used vary from $1 / 2000026$ to $37 / 100000$ (i.e. $1 / 2700)^{21}$.

Own cells may be inappropriate in conditions where the disease has a genetic origin, including some leukemia, and patients would be better served by a source other than their own-banked cells.

\section{Cost of cord blood banking}

There are usually two fee associated with cord blood banking: The first is the initial fee which includes enrollment, collection and storage for the first year. The second is an annual storage fee. The initial fee will range from $\$ 900$ to $\$ 2100$ depending on the predetermined period of storage. Annual storage fees beyond the initial storage fee are approximately $\$$ $100^{1,12}$.

\section{Advantages and disadvantages of the use of cord blood:}

The availability of cord blood as an alternative to bone marrow as a source of HSC for allogeneic transplantation has a number of potential advantages. For example, Patients can receive cord blood transplantation earlier than those receiving conventional bone marrow grafts ${ }^{23}$. Again, Cord blood transplantation will tolerate a mismatch of tissue types between donor and the recipient greater than is acceptable with bone marrow or peripheral blood. Moreover, there is lower incidence and severity of graft versus host disease and viral transmission: in particular, cytomegalovirus and Epstein-Barr virus

The disadvantages of cord blood transplantation include: low numbers of haemopoetic progenitor cells and stem cells in each cord blood donation, which may cause delayed engraftment. This deficiency is being addressed by the use of multiple units of cord blood for transplantation, and by efforts to expand the progenitor pool. Lack of availability of subsequent donations of stem cells and/or lymphocytes from the graft donor in graft failure or disease relapse ${ }^{24}$.It is possible that genetic diseases may be present but not apparent at the time of birth and could be transplanted to a patient via donor cord blood stem cells ${ }^{5}$.

Diseases treated with cord blood stem cells: Nearly seventy diseases can be treated with the transplantation of bone marrow. Most of the bone marrow failure disorders, hemoglobinopathies, histiocytic disorders, inherited immune system disorders, inherited metabolic disorders, leukemia and lymphomas, myelodysplastic/ myeloproliferative disorders, plasma cell disorders and some malignancies can be treated with umbilical cord blood transplantation. Moreover, research is going on for the treatment of Alzheimer's, Parkinson's, heart and liver disease, diabetes, muscular dystrophy, spinal cord injury and stroke. 


\section{Cord Blood Stem Cell Expansion:}

Umbilical cord blood stem cell expansion is currently an experimental procedure where a collection of stem cells in the laboratory are placed in a growth medium and allowed to reproduce, thereby increasing the number of available cells. The cell dose of cord blood grafts remains of critical importance for speed of engraftment and survival after unrelated cord blood transplantation from unrelated donors, particularly in adults. A minimum total nucleated cell dose of $2.0 \times 10^{7} / \mathrm{kg}$ recipient body weight is essential and most centers use a threshold much higher than this. In some cases, this procedure may be necessary to provide sufficient number of cells for transplant ${ }^{25,26}$. The stem cells have been shown to reproduce in vitro (in the laboratory) just as they do in own bone marrow. Some studies have shown cell expansion has increased the number of stem cells up to 100 times the original number. Cell expansion is the key for recovering enough cells to treat an adult patient ${ }^{12}$.

\section{Logistical issues:}

There are a number of practical issues that give cause for concern. A considerable logistic burden is imposed on the obstetrician or midwife and the hospital for cord blood storage. The consent procedure, associated paperwork and collection procedure place an additional load on already overstretched midwifery staff. The cord blood can become contaminated with bacteria during collection unless stringent precautions are taken to avoid this ${ }^{27}$ .The use of midwifery or medical staff for cord blood collection may distract them from the care of other mothers and babies and routine maternal or neonatal observations may be neglected ${ }^{24}$.

Beside these there are some specific issues in the third stage call for attention. For example: early cord clamping appears to be disadvantageous to the preterm infant. Preterm babies are at risk of anaemia and haemodynamic instability. From a systematic review of seven randomized controlled trials there is some evidence that $30-120$ seconds delay is associated with fewer transfusions for anaemia and fewer intraventricular haemorrhages. ${ }^{28}$

Cord around the neck may also need to be released or cut early to allow delivery. There should be no pressure on attendants to avoid cutting the cord.
Standard practice at caesarean delivery is to clamp the cord immediately and pass the infant to an attendant, then deliver the placenta, and proceed to repair the uterine incision. Rapid action minimizes maternal blood loss from surgery. So it will be inappropriate to do undue delay in collection of cord blood where there is increased risk of haemorrhage.

The logistical burden of collection increases at twin and high order multiple deliveries. The accoucheur's attention has to be more focused on minimising adverse fetal outcome and postpartum haemorrhage during the time of cord blood collection. Again, identifying which cord blood is associated with which infant in non-identical multiple births is necessary if the cord is for autologous use $\mathrm{e}^{24}$.

\section{Legal and ethical issues:}

Legality of parental consent to take cord blood When the child is delivered, it becomes a person legally and the parents' right to dictate what shall be done to the child is coterminous with the child's best interests. The parents cannot demand that anything be done to the child that may have the effect of putting the child at risk, unless it is in the best interests of the child. This applies to the birth attendants as it does to the paediatrician. However, legally, the placenta is part of the body of the mother rather than the child. Either parent is competent to give consent to anything done to or for the baby but only the mother can give consent to anything done to her own body, including cord blood collection ${ }^{24}$.

Decision to donate: decision to donate cord blood for use by other individuals is made by the mother as the cord blood, being taken from the maternal side of the clamp, is not part of the independent child's body. The decision to donate to the community should be taken by the mother in the best interests of the society.

Privacy is of special concern, since the source of the blood is the newborn, and it is widely agreed that it would be inappropriate to perform any genetic tests on the blood that would not be directly in the interests of the child until he or she is 18 years of age or is able to make such decisions ${ }^{29,30}$.

Whose blood is it?

It has been suggested that the cord blood sample is more likely to be the property of the child on the basis 
that it is developmentally, biologically and genetically part of the child. ${ }^{17,31}$ On the other hand; once the cord is cut it is mother's property. So the cord blood consigned to storage may be the subject of a gift from the mother to her child depending on the terms of the consignment.

As a result, autologous low-risk commercial storage is unlawful in Italy and discouraged in some other European states. In 2004, the European Group on Ethics in Science and New Technologies advised European Commission that: 'The legitimacy of commercial cord blood banks for autologous use should be questioned as they sell a service, which has presently, no real use regarding therapeutic options. Thus they promise more than they can deliver. The activities of such banks raise serious ethical criticisms'. The group did not go as far as recommending banning this activity but they also recommended that: 'any kind of advertising made by commercial cord blood banks in the media, including on the Internet, must be adequately controlled by public authorities'. They recommended that 'support for public cord blood banks for allogeneic transplantations should be increased and long-term functioning should be assured'. ${ }^{21}$

In Canada, the Fetal Medicine Committee of the Society of Obstetrician and Gynaecologists recommended that Canada should establish registration, regulation and accreditation of cord blood collection centers and banks and those commercial cord blood banks should be carefully regulated. $^{22}$

Royal College of Obstetrics and Gynaecology strongly supports the concept of an NHS Cord Blood Bank for allogeneic storage of donated cord blood and would like to see it well funded. However, it remains unconvinced of the benefit of personal commercial banking for low-risk families.

The RCOG offers the following specific recommendations to them who decide to support cord blood collection:

a. There should be no alteration in 'usual management' of the third stage.

b. To maximize safety for the mother and infant, collection should be made from the ex utero separated placenta.

c. Collection should be by a trained third party (that is, not by the attending obstetrician or midwife) using appropriate methods and facilities d. The service should not be made available in cases where the attending clinician believes it to be contraindicated: this will be likely to include all premature births and cases where there appear to the attendants to have specific contraindications, such as nuchal cord or maternal haemorrhage.

e. The details of the hospital's policy should be made available to all patients.

\section{Conclusion:}

Umbilical cord blood has become an established alternative to bone marrow transplantation, especially in haematological, immunological and metabolic storage disorders in children and young adults. In addition to those life-saving capabilities, research is already uncovering cord blood stem cell applications in the treatment of Alzheimer's, Parkinson's, heart and liver disease, diabetes, muscular dystrophy, spinal cord injury and stroke. In Bangladesh, we are far away from this practical method. But Scientists working in blood bank; haematologists, obstetricians as well as social workers need to think and work together regarding the possibility of the establishment of this valuable program.

\section{References:}

1. Cord Blood Bank. Available at en.wikipedia.org/wiki/cord blood bank, accessed on 27 May 2008

2. Samuel GN, Kerridge IH, O'Brein TA. Umbilical cord blood banking: public or private benefit?Med J Aust .2008May;188(9):533-5.

3. Solve P, Mirabet V, Perales A, Carbonell-uberos F, Roig R. Banking strategies for improving the hematopoietic stem cell content of umbilical cord blood units for transplantation. Stem Cell ResTher. 2008 May; 3(2):79-8

4. Magin AS, Koerfer NR, Partenheimer H, Lange C, Zander A, noll T. Primary Cells As Feeder Cells For Coculture Expansion Of Human Hematopoietic Stem Cells From Umbilical Cord Blood A Comparative Study.Stem Cells Dev.2008, Germany.

5. Cord Blood Stem Cell Transplantation. The Leukemia and Lymphoma Society, New York.Available at www. LLS.org IRC 800.955.4572 accessed on 28May2008

6. Banking your newborn's Cord blood. Available at www.Kids health.org/parent/pregnancy_newborn/pregnancy/cord_blood. html. accessed on 6 June 2008.

7. Gluckman E. Haemopoetic stem-cell transplants using umbilical-cord blood. N Engl J Med 2001;344:1860-1.

8. Kogler G, Sensken S, Airey JA, Trapp T, Muschen M, feldhahn $\mathrm{N}$, et al. a new human somatic stem cell from 
placental cord blood with intrinsic pluripotent differentiation potential. J Exp Med 2004;200:123-35.

9. McGuckin CP, Forraz N, Baradez MO, Navran S, Zhao J, Urban R,et al. Production of stem cells with embryonic characteristics from human umbilical cord blood. Cell Prolif 2005;38:245-55.

10. Hoffbrand AV, Petit JE, Moss PAH. Essential Haematology, UK, Blackwell Science Ltd, 2001: 98-110

11. Fox NS, Stevens C, Ciubotariu R, Rubinstein P, McCullough LB, Chervenak FA.Umbilical cord blood collection: do patients really understand? J Perinat Med. 2007;35(4):314-21.

12. The Stem cell controversy. New England Blood Bank. Available at ncbi.nlm.nih.gov accessed on 27 May 2008

13. Solves P, Mirabet v, Perales A, Carbonell-Uberos E, Roig R. Banking stratigies for improving the hematopoietic stem cell content of umbilical cord blood units for transplantation. Stem cell Res Ther. 2008 May;3(2):79-84

14. Sears R. Banking Your Baby's Cord Blood- A serious Option for Pregnant Parents to consider.Available at www.askdrsears.com/html Accessed on 5 May 2008.

15. Kobulka, Peter Z, Ivanyi, Pavol, Bruer-Vrie sendrop, Brigitta. Preservation of immunological and Colony-Forming Capacities of Long Term (15 years)Cryopreserved Cord Blood Cells.Transplantation1998;65(9):1275-1278.

16. Hows JM, Status of umbilical cord blood transplantation in the year 2001. J Clin Pathol 2001;54:428-34

17. Annas GJ. Waste and longing- the legal status of placentalblood banking. N Engl J Med 1999;340:1521-4.

18. Ecker JL, Greene ME. The case against private umbilical cord blood banking. Obstet Gynaecol 2005;105:1282-4.

19. Gunning J. Umbilical Cord Cell Banking: A Surprisingly controversial issue. Cardiff: Cardiff Centre of Ethics, Law and Society; 2004 [www.ccels.cf.ac.uk /literature/ publications/2004/gunningpaper.pdf]

20. Johnson FL. Placental blood transplantation and autologous banking-caveatemptor. J Pediator Hematol Onco 1997;19:183-6.
21. Ethical aspects of umbilical cord blood banking: Opinion of the European Group on Ethics in Science and New Tecnologies to the European Comission. No. 19 16th March 2004 [http://europa.eu.int/comm./european_group_ethics/ docs/avis19_en.pdf]

22. Armson BA.Maternal/Fetal Medicine Committee, Society of Obstetricians and Gynaecologists of Canada. Umbilical Cord Blood Banking: Implications of perinatal care providers. J Obstet Gynaecol Can 2005;27:263-90.

23. Barker JN, Krepski TP, DeFor TE, Davies SM, Wagner JE, Weisdrof DJ. Searching for unrelated donor hematopoietic stem cells: Availability and speed of umbilical cord blood versus bone marrow. Biol Blood Marrow Transplant, 2002;8:257-60.

24. Bruude P. et al.Umbilical Cord Blood Banking, Opinion Paper 2. London. SAC, RCOG. 2006.( www.rcog.org.uk)

25. Bornstein R, Flores AI, Montaban MA, del Rey Mj, de la Serna J, Gilsnaz F. A modified cord blood collection method achieves sufficient cell levels for transplantation in most adult patients. Stem Cells 2005;23:324-34.

26. Rachael E Hough, Ajay J Vora, John E Wagner. Innovative strategies to improve outcome of unrelated donor umbilical cord blood transplantation. Bloodmed 2005[www.bloodmed.com/400000/default.asp]

27. Armitage S, Warwick R, Fehily D, Navarette C, Contrarus M, Cord blood banking in London: the first 1000 collections. Bone Marrow Transplant 1999;24:139-45.

28. Rabe H, Reynolds G, Daiz-Rossello J. Early versus delayed umbilical cord clamping in preterm infants. Cochrane Database Syst Rev 2004;(4):CD003248.

29. Marshall E. Cord blood: clinical promise, ethical quandary. Science 1996;271:586-8.

30. Zilberstein M, Feingold M, Seibel MM. Umbilical-cordblood banking: lessons learned from gamete donation. Lancet 1997;349:642-3.

31. Munzer SR. The special case of property rights in umbilical cord blood for transplantation. Rutgers Law Rev 1999;51:493-568. 